\title{
Commentary
}

\section{Tackling Gender and Racial Inequities: Climate Solutions for All}

Kathryn Mary Stone ${ }^{1}$, BSc; Emma Stirling Cameron ${ }^{1}$, BSc; Rebecca Spencer ${ }^{1}$, PhD; and Barb Hamilton-Hinch ${ }^{1,2}$, PhD

${ }^{1}$ School of Health and Human Performance, Dalhousie University

${ }^{2}$ Healthy Populations Institute, Dalhousie University

https://doi.org/10.15273/hpj.v1i1.10656

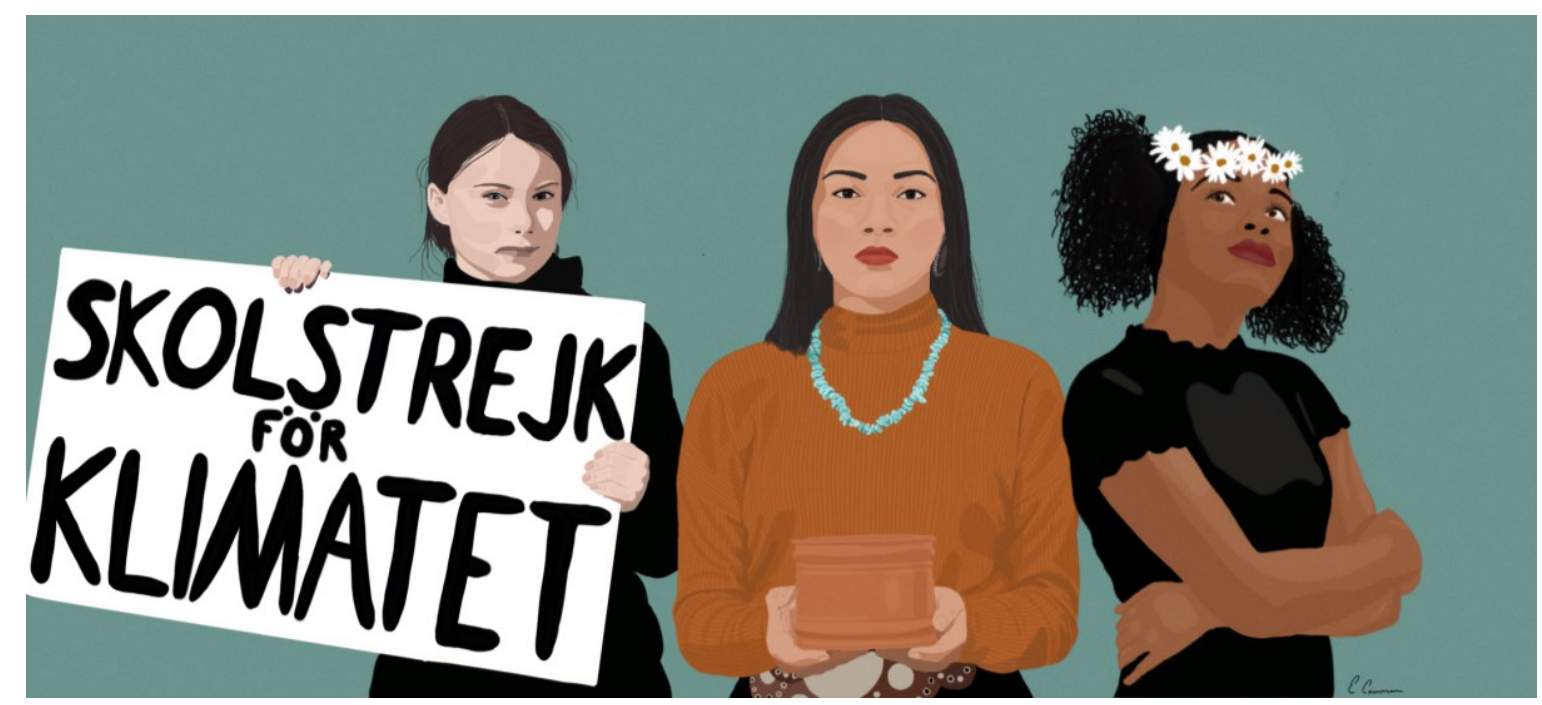

Image depicts three young women known for their environmental and human rights activism. From left to right, Greta Thunberg, Autumn Peltier, and Mari Copeny (Little Miss Flint) exemplify the knowledge, power, and experience of organized justice movements needed to address the climate crisis. Artwork by ESC. 
Climate change has been labeled the "biggest global health threat in the $21^{\text {st }}$ century" (Costello et al., 2009, p. 36). This statement, now a decade old and commonly repeated in climate and health discourse, is only partly true because it neglects to consider the social context of climate change. Hurricanes are increasingly more frequent and less predictable, droughts and fires are more widespread, sea ice continues to melt, and sea levels rise. Populations who have been marginalized, including women, Indigenous peoples, people of colour, and people with low income or in low-income countries, experience the brunt of the climate crisis (Hayes \& Poland, 2018). There is significant overlap between racial and gender inequities and the climate crisis, and tackling oppressive systems may be key to sustaining life on earth. We will need the strongest climate team, the most inclusive and powerful solutions, and the knowledge to dismantle the similar systems and structures that simultaneously sustain oppression and climate change.

\section{The Strongest Team}

Dr. Ayana Elizabeth Johnson, marine biologist and climate activist, suggests the climate movement will not have sufficient numbers if people of colour are excluded; we cannot address the climate crisis unless Black Lives Matter (Johnson, 2020). To be successful, we need the biggest, brightest team there isthe problem cannot be solved with the voice of one demographic. White people, often overrepresented in the environmental movement, have regularly seen climate change as a more important issue than racial justice, and therefore exclude people of colour from their work (Heglar, 2020). Additionally, BIPOC (Black, Indigenous, and People of Colour) women are battling White supremacy and the patriarchy simultaneously with the climate crisis. How can they devote time to climate change while living in a system designed to oppress, incarcerate, or disregard specific important segments of the population? How can we ask that BIPOC folks commit themselves to the crisis with White supremacy standing in the way? Racism thwarts efforts to address climate change because it successfully distracts, drawing attention from one crisis to another. We need to remove barriers so that everyone is welcome at the climate solutions table, because not only is everyone worthy of a seat, but everyone is essential.

\section{Better Solutions for All}

Reducing inequities is imperative, not only so that those who have been marginalized fare better through the climate crisis, but also because those who have been closest to climate impacts are the ones who have the solutions. Women and BIPOC communities are disproportionately impacted by the climate crisis. Women worldwide are increasingly likely to experience gender-based violence during and after extreme weather, as well as during prolonged drought and food scarcity (Alston, 2013). Ice melting drastically impacts the time that Inuit communities can be on the land, reducing time spent visiting other communities, fishing, foraging, hunting, and trapping, and this impact on the landscape and their cultural traditions results in a deep sense of loss (Willox et al., 2015). Black Americans experience the brunt of climate catastrophes such as Hurricane Harvey and Katrina. Communities of colour are often situated in floodplains and lack green space to absorb water (Frank, 2020).

Due to their disproportionate experiences of climate change and colonial violence, Black and Indigenous women have been organizing social and environmental justice work for decades in order to protect themselves, their communities, and the land (Waldron, 2018). This practice of resistance and resilience is what we need to address the climate. Young women, in particular, are making their own climate solutions tables: Autumn Peltier, Mari Copeny, and Greta Thunberg are representative of thousands of youth striking and sacrificing their education, advocating for clean water, and fighting to protect Mother Earth. Further, Indigenous peoples have been living harmoniously with the land since time immemorial, meaning not only 
that it can be done, but that those who know how are living all over the world, ready to be listened to as stewards of the earth. Whether it be protecting the Sipekne'katik River from the brine discharge pipeline (Waldron, 2018), saving the Amazon forests (Nenquimo, 2020), overcoming voter suppression to elect a president with a climate action plan (Scanlan \& Robinson, 2020), or school striking (Boulianne et al., 2020), the passion, knowledge, and leadership of women and BIPOC people across the world is what could save Earth.

\section{Similar Systems and Structures}

We cannot separate issues of racism, misogyny, and climate change. Waldron (2018) argues that we must move beyond discussion of industry causing environmental degradation, and toward how these issues are interconnected. The interconnection of these issues begins with legacies of enslavement, labour, and colonization. The intention of European colonists was to dispossess Indigenous peoples of their land so that colonists could extract resources and exploit land with the use of enslaved African and Indigenous peoples (Elliott \& Hughes, 2019). As a result of this, Black and Indigenous people have suffered and continue to experience extreme violence, death, and injustice, while at the same time their labour and land was used to set the stage for global industrialization and the beginning of the fossil fuel era-which continues to warm planet Earth (Costello et al., 2009; Delaney, 2020; Waldron, 2018). Although these events took place generations ago, modern industry continues to use fossil fuels and harm the same populations. For example, today, resource extractive industries often set up "man camps," where mostly White men live in temporary homes near the construction sites at which they work (National Inquiry into Missing and Murdered Indigenous Women and Girls [NIMMIWG], 2019). These camps significantly increase violence against Indigenous women, girls, and Two Spirit people (NIMMIWG, 2019). This extractive system simultaneously pillages the planet's resources and perpetrates violence against Indigenous people. Dismantling systems of harmful resource extraction not only tackles climate change, but also protects BIPOC women.

While it may be possible to reduce greenhouse gas emissions without addressing systems of oppression (for example, by producing electric cars), if we do not change the exploitative system at its core, we risk missing our chance at truly respecting the planet in a way that is sustainable for everyone. What kind of world would you like to live in after we have saved the planet? One that is safe from climate change but not police brutality and colonial violence? Or one with health equity, cultural sharing, and peace? To save the earth from mass extinction, we need to dismantle inequities and centre the voices of women, specifically, Black and Indigenous women and women of colour.

\section{References}

Alston, M. (2013). Women and adaptation. Wiley Interdisciplinary Reviews: Climate Change, 4(5), 351-358. https://doi.org/10.1002/wcc.232

Costello, A., Abbas, M., Allen, A., Ball, S., Bell, S., Bellamy, R., Friel, S., Grace, N., Johnson, A., Kett, M., Lee, M., Levy, C., Maslin, M., McCoy, D., McGuire, B., Montgomery, H., Napier, D., Pagel, C., Patel, J., ... . Patterson, C. (2009). Managing the health effects of climate change. The Lancet, 373(9676), 1693-1733 https://doi.org/10.1016/s01406736(09)60935-1

Delaney, R. (2020, November 2). Racial justice is climate justice [Video]. https://davidsuzuki.org/story/racialjustice-climate-justice/

Boulianne, S., Lalancette, M., \& Ilkiw, D. (2020). "School Strike 4 Climate": Social media and the international youth protest on climate change. Media and Communication, 8(2) 208-218. http://dx.doi.org/10.17645/mac.v8i2.2 768 
Elliott, M., \& Hughes, J. (2019, August 19) Four hundred years after enslaved Africans were first brought to Virginia, most Americans still don't know the full story of slavery. The New York Times Magazine. https://www.nytimes.com/interactive/ 2019/08/19/magazine/historyslavery-smithsonian.html

Frank, T. (2020, June 2). Flooding disproportionately harms Black neighborhoods. E\&E News. https://www.eenews.net/special_repor ts/EEnews_highlights/stories/1063295 449

Hayes, K., \& Poland, B. (2018). Addressing mental health in a changing climate: Incorporating mental health indicators into climate change and health vulnerability and adaptation assessments. International Journal of Environmental Research and Public Health, 15(9), Article 1806. https://doi.org/10.3390/ijerph150918 06

Heglar, M. A. (2020, June 12). We don't have to halt climate action to fight racism. Huffpost. https://www.huffingtonpost.ca/entry/c limate-crisis-racism-environmenaljustice_n_5ee072b9c5b6b9cbc7699c3d ?ri18n=true

Johnson, A. E. (2020, July 9). We can't solve the climate crisis unless Black Lives Matter. TIME. https://time.com/5864705/climatechange-black-lives-matter/

National Inquiry into Missing and Murdered Indigenous Women and Girls. (2019). Reclaiming power and place: The final report of the National Inquiry into Missing and Murdered Indigenous Women and Girls, Volume 1a. (Report No. CP32-163/2-1-2019E-PDF). https://www.mmiwg-ffada.ca/wp-
content/uploads/2019/06/Final_Repor t_Vol_1a-1.pdf

Nenquimo, N. (2020, October 12). This is my message to the western world - your civilization is killing life on Earth. The Guardian.

https://www.theguardian.com/comme ntisfree/2020/oct/12/westernworldyour-civilisation-killing-life-onearth-indigenous-amazon-planet

Scanlan, Q., \& Robinson, A. (2020, November 12) Stacey Abrams says efforts against voter suppression made "the difference" in Georgia. $A B C$ News. https://abcnews.go.com/Politics/stace $\mathrm{y}$-abrams-voter-suppression-effortmade-differencegeorgia/story?id=74146679

Waldron, I. R. G. (2018). Women on the frontlines: Grassroots movements against environmental violence in Indigenous and Black communities in Canada. Kalfou, 5(2). https://doi.org/10.15367/kf.v5i2.211

Willox, A. C., Stephenson, E., Allen, J., Bourque, F., Drossos, A., Elgarøy, S., Kral, M. J., Mauro, I. Moses, J., Pearce, T., MacDonald, J. P., \& Wexler, L. (2015). Examining relationships between climate change and mental health in the Circumpolar North. Regional Environmental Change, 15(1), 169-182. https://doi.org/10.1007/s10113-0140630-z 